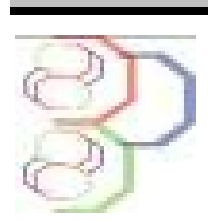

\title{
Survey and cartography of the spatial variation of the pollution of the waters from well of some districts of the township of Abomey-Calavi, Benin.
}

\author{
Parfait HOUNSINOU1*, Daouda MAMA ${ }^{1}$, Flavien DOVONOU1, Abdoulkarim ALASSANE1, Aristide \\ AKPO $^{2}$ and Moussa BOUKAR ${ }^{1}$ \\ 1 Laboratoire d'Hydrologie Appliquée, Faculté des Sciences et Techniques, Université d'Abomey - Calavi, Bénin. \\ 2 Laboratoire de la Physique du Rayonnement, Faculté des Sciences et Techniques (FAST), Université d'Abomey- \\ Calavi, Bénin. \\ ${ }^{*}$ Corresponding author: H. Parfait, tél: 00229 95155105; E-mail: doctorantparfait@yahoo.fr
}

Original submitted in on $8^{\text {th }}$ December 2014. Published online at www.m.elewa.org on $30^{\text {th }}$ January 2015 http://dx.doi.org/10.4314/jab.v85i1.3

\begin{abstract}
Objective: The objective of this work was conducted to study and map the spatial variation of the physical, chemical and microbiological contamination of well water in some areas of the town of Abomey-Calavi in Benin.

Methods and Results: The methods used to measure physical and chemical parameters are those spectrophotometric, colorimetric, conductivity and some other methods recommended by the French Association for Standardization (AFNOR). Microbiological parameters were measured according to the method by incorporating agar described in the book Rodier and maps were produced by Arc View 3.2 software. On the physical and chemical level, $50 \%$ of the analyzed well water have a normal pH and are all located at the lake. All analyzed well water has a redox potential higher than normal with the highest values for wells along the lake. Lead and zinc concentrations in these waters comply with WHO standards. Bacteriological analyzes showed that all well water pollution reveal bacteria such as thermotolerant coliforms, intestinal enterococci, total coliforms with the highest concentrations in the wells located on Lake Nokoué. This indicates that the water may be responsible for the spread of waterborne diseases. The ratio thermotolerant coliforms and intestinal enterococci show that the origin of faecal contamination of human type in $50 \%$ of the wells. Faecal contamination of human kind concerns all the lake nearby well and the animal type concerns distant wells that lake.

Conclusion and Application: These cards will attract the attention of people in the town of Abomey-Calavi and policy makers on areas where well water are the most polluted.
\end{abstract}

Key words: physical chemical and microbiological quality, well water, pollution, mapping.

\section{INTRODUCTION}

The water resources of the earth are enormous but limited. Atmospheric pollution is at the origin of the destruction of the ozone layer and the last is at the origin of the climatic warming up that has disastrous effects. Among other, the climatic warming up dries out water from (lakes, lagoons, streams). As oil in our days, water risks to become therefore a fundamental stake in the future. Water 


\section{Hounsinou et al.. J. Appl. Biosci. Survey and cartography of the spatial variation of the pollution of the}

waters from well of some districts of the township of Abomey-Calavi, Benin.

could become during the next century, the stake of large-scale commercial and geopolitical conflicts and therefore, it can cause the 3rd world war (Monjour 1997). Nowadays, the problem of water is already critical in the under developed countries where very little people have access to drinking water. In Benin, because of the insufficient financial means, a large majority of the population (65\% about) did not register with the National Water Corporation (Agassounon Tchibozo et al 2010). This population consumes waters of well in general without a previous treatment and is exposed to numerous diseases. In the township of Abomey-Calavi (South - Benin), during the rainy season, several people are affected by water related diseases of which cholera, that is provoking some deaths. The population of the township of Abomey-Calavi essentially consumes underground water from traditional wells and (or filtered water treated and delivered by the SONEB). This underground water deserves a particular attention then. The recrudescence of the illnesses related to water during the season of rains testifies the acquirement of the pollutants by the underground waters from the waters of rains and the waters of surface. The diagnostic of the acquirement of the

\section{MATERIALS AND METHODS}

PRESENTATION OF THE SURVEY ZONE : AbomeyCalavi is a Beninese city, situated in the department of the Atlantic (South - Benin). The city spreads on a surface of $650 \mathrm{~km}^{2}$ and accounts 307,745 inhabitants since the last census of the population of 2002. Surrounded by the townships of Sô-Ava, Bopa and Tori-Bossito, Abomey-Calavi is located 13km Northwest of Cotonou the economic capital of Benin. Situated at $12 \mathrm{~km}$ of altitude, the city of Abomey-Calavi has for geographical parameters $6^{\circ} 27^{\prime} 0$ North and $2^{\circ} 21^{\prime} 0$ East. The township of Abomey-Calavi today is subject to the influence of the proximity of Cotonou. Indeed, the narrowness of the site of Cotonou and strong population drives to an extension toward AbomeyCalavi. The most important waters that cross the township of Abomey-Calavi are the lagoon of Djonou and the Nokoué Lake. The biggest part of the territory of the Township of Abomey-Calavi is occupied little by the tropical ferruginous soils and the gritty soils auspicious to agriculture. Hydromorphic and liable to pollutants by the underground waters in the township of Abomey-Calavi is especially important, the underground waters of the township of Abomey-Calavi are the most exploited of Benin. These waters are appropriated, treated and used by the SONEB to serve drinking water to the population of the township of Abomey-Calavi, Cotonou (biggest of Benin) and the city of Sèmè. The population of Abomey-Calavi essentially consumes the underground waters from the traditional wells and drilling (adduction of water villager and waters of boring treated and stake at the disposal of the population by the SONEB). It is therefore judicious to do the present study under the title: "Methodology and diagnostic of the acquisition of the pollutants by the underground waters from the rainwater and the surface water in the township of Abomey-Calavi (south Benin)". This work is a very important tool to undertake an efficient remedy of the pollution of these waters. Indeed, this work permits us to study and to map out the spatial variation of the pollution of the waters of well of some districts of the township of Abomey-Calavi. It permits to identify the sources and the size of the pollution according to the zones and to consider some remedies.

flooding soil occupy a part of the north of the territory. The arable earths are estimated at $465.5 \mathrm{~km}^{2}$. The plant table setting of the township varies according to the crossed feature. Thus, one meets of it the mangrove swamp to mangroves in the inshore zone; a savannah damaged on the tray, of the market cultures along the swamps, a grassy grouping in the marshes and along the banks of the Nokoue Lake. The township of Abomey-Calavi is situated in the intertropical zone. In this zone, the climate is of subequatorial type characterized by two (02) seasons of rains (of September to November and March to July) and two (02) dry seasons (of November to March and July to September). The township spreads on two (02) big geological formation types. The quaternary formations that are sandy deposits of the coastal cord, of the lagoon deposits makes of clay and sand and deposits constituted alluvium of sand and clay. The tertiary formations as for them are essentially constituted of clay and sand. 

waters from well of some districts of the township of Abomey-Calavi, Benin.

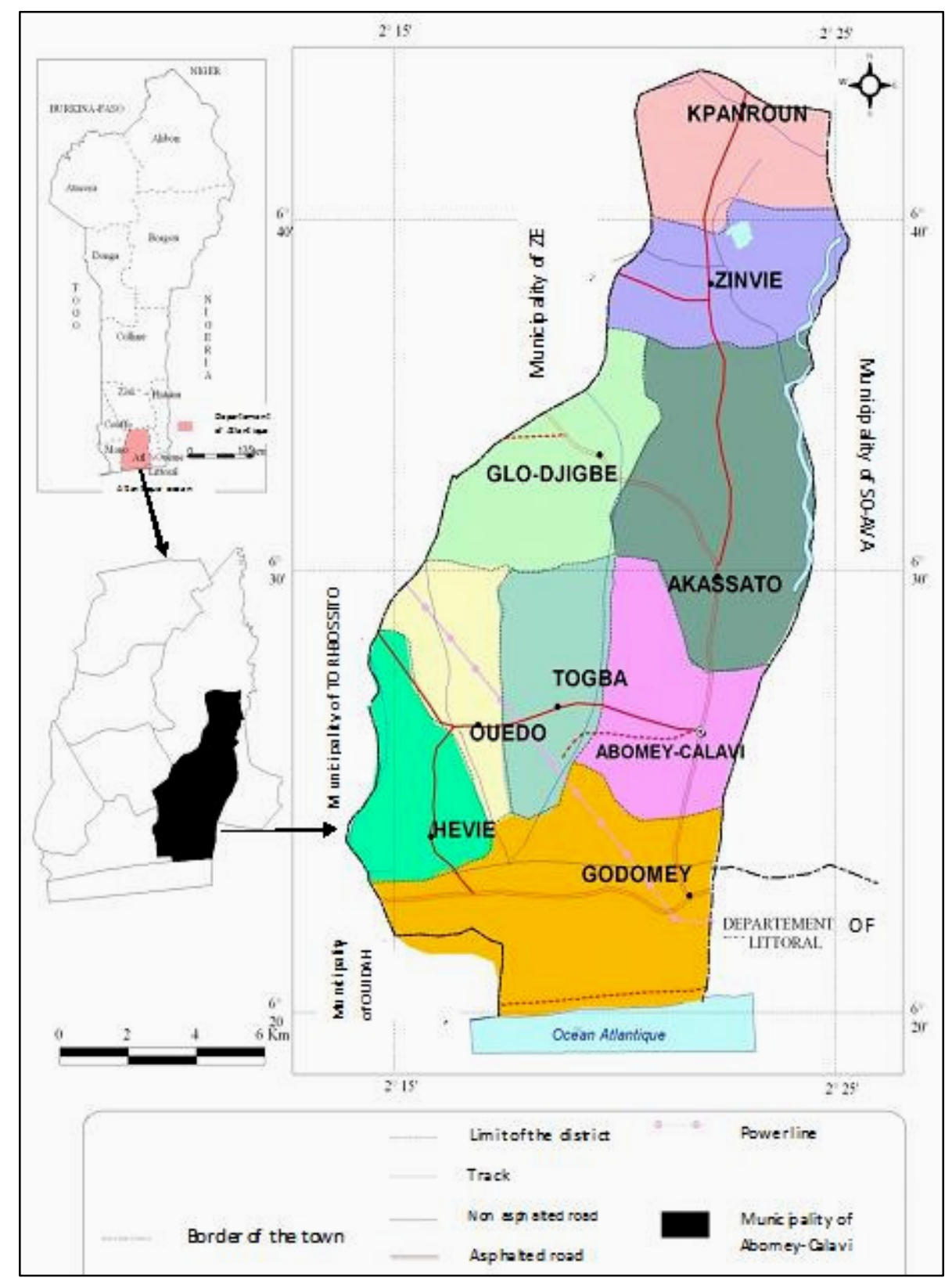

Picture 1: Location of the municipality of Abomey-Calavi.

\section{SAMPLING}

The township of Abomey-Calavi is a township of Benin in which water from wells is essentially used (the traditional wells and the boring). Water of drilling type is relatively of good quality. Water from traditional wells of the township of Abomey-Calavi is all polluted (Bossou 2002, Degbey, 2004, Hounsinou, 2012). The township of Abomey-Calavi counts nine (09) districts of which the district of Abomey-Calav is the less equipped with drills. In the precinct of Abomey-Calavi on average, there is a traditional well by house. The waters of these wells are all polluted. In particular, those that are close to the Nokoue Lake are the most vulnerable. Indeed, these last are of weak depths (20 m about) and are exposed to the faecal pollution especially by the septic pits and by the waters of infiltration. Twenty (20) representative samples of these wells are the object of the present survey 
Hounsinou et al.. J. Appl. Biosci. Survey and cartography of the spatial variation of the pollution of the waters from well of some districts of the township of Abomey-Calavi, Benin.

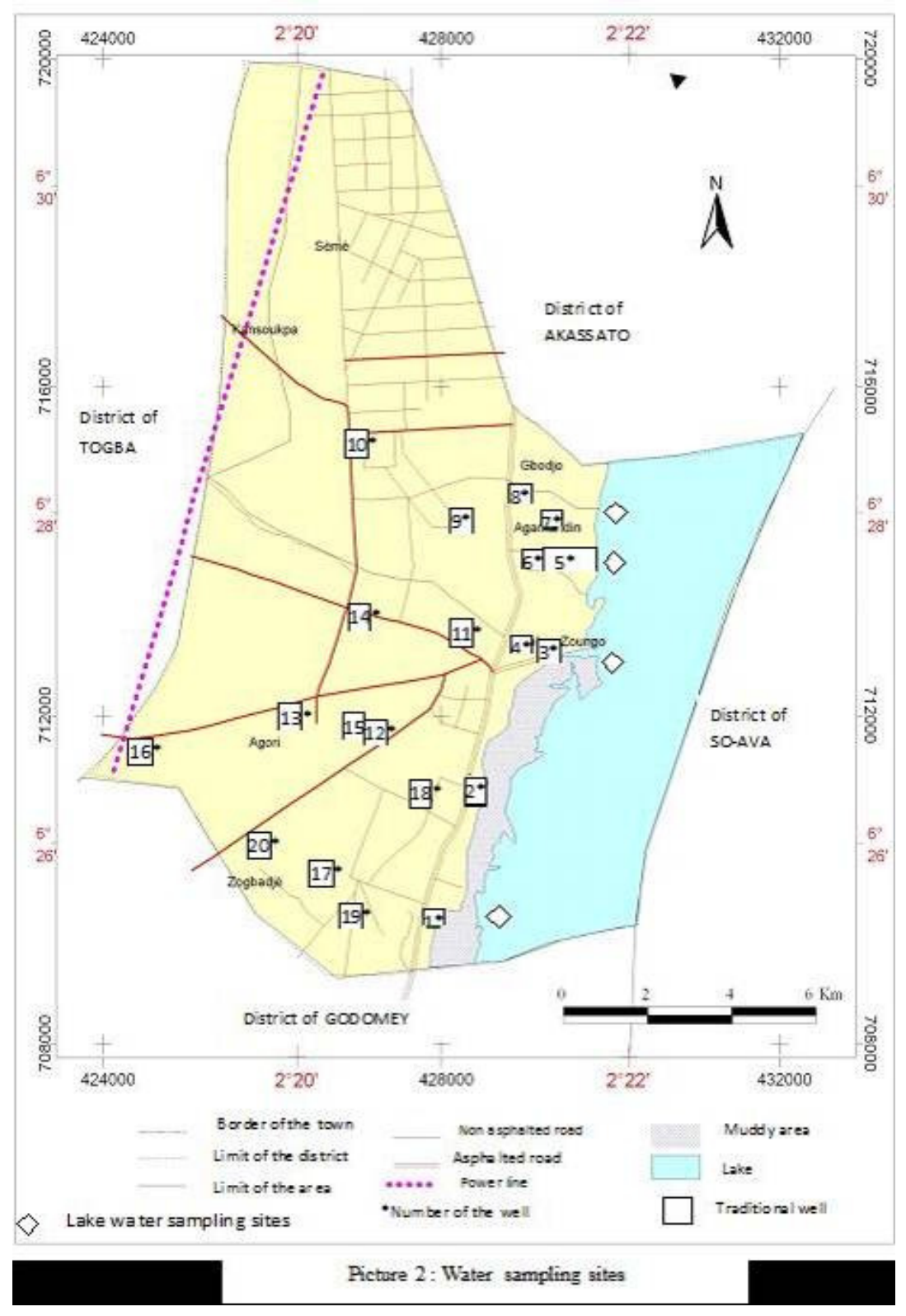

\section{CARTOGRAPHY AND DOSAGE}

The particulars of the wells have been used to achieve the cards of distribution of the wells with the help of the software Area view 3.2. During our survey on the field, (January to March 2013), the physical and chemical parameters $(\mathrm{pH}$, temperature, dissolved oxygen, conductivity, dissolved salt) have been measured in situ. The samples of waters intended to the chemical analyses have been appropriated in clean covered plastic bottles, which were previously labelled. The withdrawals of waters intended to the microbiological analysis in the wells have been achieved with the help of the sterilized small bottles labelled previously, attached each by a thread clean to the tip of which is fixed a stone. It permits to prefer to about $50 \mathrm{~cm}$ of the surface free of water contained in the well. Once full of water, the small bottles were pulled back up from the wells, closed and placed in the icebox, which is planned to contain them. It is placed there among ice pieces so that the microbiological parameters are not modifying because of the temperature variations. Then the samples are transported to the laboratory so that microbiological analysis can be performed. According to the physical and chemical parameters to measure where the ions to measure out different methods, 


\section{Hounsinou et al.. J. Appl. Biosci. Survey and cartography of the spatial variation of the pollution of the}

waters from well of some districts of the township of Abomey-Calavi, Benin.

described in the chemistry general works, have been used. The temperature, the $\mathrm{pH}$, the dissolved oxygen, the rate of oxygen saturation and the potential redox have been measured by a pH/oxymeter according to the norm AFNOR NF IN 25814.

The saltiness, the conductivity and the TDS have been measured by conductivity.

The turbidity is measured by colorimeter.

Lead and zinc are measured out by spectrophotometry.

The microbiological parameters (Escherichia coli, total coliforms, intestinal enterococci, coliforms thermotolerants and banal germs) have been measured according to the method by incorporation in agar-agar described in the book the Rodier. The results of the measures of the physical and chemical parameters and the heavy metals of the waters of well are consigned in the picture 1 and the results of the measures of the microbiological parameters of the waters of well are consigned in the picture 2. We present here the distribution of the values of these parameters in the zone of survey. To really interpret these results, we measured the physical and chemical parameters and of the heavy metals in the waters of the Nokoue lake and in the rainwater in the zone of survey.

\section{RESULTS AND INTERPRETATIONS OF THE PHYSICAL AND CHEMICAL PARAMETERS AND THE HEAVY METALS}

$\mathrm{pH}$ : The $\mathrm{pH}$ informs on the activity or the alkalinity of a solution. The $\mathrm{pH}$ of the waters of surface and the underground waters is bound to the nature of the rocks crossed. The $\mathrm{pH}$ of the rainwater reflects the nature and the size of the air pollutants. Rain very industrialized country is acidic because of the dismissals in the atmosphere of gases as the carbon monoxide, the dioxide of carbon, the dioxide of sulphur (HOUNSINOU, 2012)... According to instructions of the European Union on the $03 / 11 / 98$ concerning the quality of water, of the $\mathrm{pH}$ of water destined to the consumption must be consistent between 6.5 and 9 .

The $\mathrm{pH}$ of the studied well waters varies from 4.3 to 7.2. $60 \%$ of the wells sampled have a pH below the lower doorstep of the norm (6.5). This acidity is probably due to the geological nature of soil. It confirms the results of Bossou in 2002 Degbey in 2004, of Gomez in 2009, of Haissoufi El et al in 2011 and Hounsinou in 2012. These too acidic waters are those of the wells $n^{\circ} 9$ to the well $n^{\circ} 20$ that is relatively the most distant of the Nokoue Lake. $40 \%$ of the waters of well-sampled (well $n^{\circ} 1$ to the well $n^{\circ} 8$ ) have a $\mathrm{pH}$ compliant to the norms of the Union European. These wells are the nearest of the Nokoue lake. The average of the $\mathrm{pH}$ of these last wells (6.9) is nearly equal to the average of the $\mathrm{pH}$ of the samples of water of the Nokoue Lake (6.8) and that is nearly equal to the middle $\mathrm{pH}$ of the rainwater meteoroid (6.7) in the zone of survey. It is noted that Benin being poorly industrialized, the atmospheric pollution by the carbon monoxide, the dioxide of carbon and the dioxide of sulphur is very weak. It is why the $\mathrm{pH}$ of the rainwater meteoroid is less acidic in the zone of survey. These pluvial waters nourish the Nokoue Lake that is why the waters of this lake are almost neutral as the rainwater meteoroid. The waters of well near of the Nokoué lake come mainly from the Nokoue lake and it is why the waters of the wells $n^{\circ} 1$ to 8 are almost neutral. The variation of the $\mathrm{pH}$ of the waters of well permitted to identify the wells whose pollution is susceptible influence by the waters of the Nokoue lake. It is about the wells $n^{\circ} 1$ to 8 . Let us underline that the life span of the bacteria is shorter in acidic soils (pH between 3 and 5) that in the alkali soils. The $\mathrm{pH}$ of the wells near of the lake is more favourable to the development of the microorganisms. 

waters from well of some districts of the township of Abomey-Calavi, Benin.

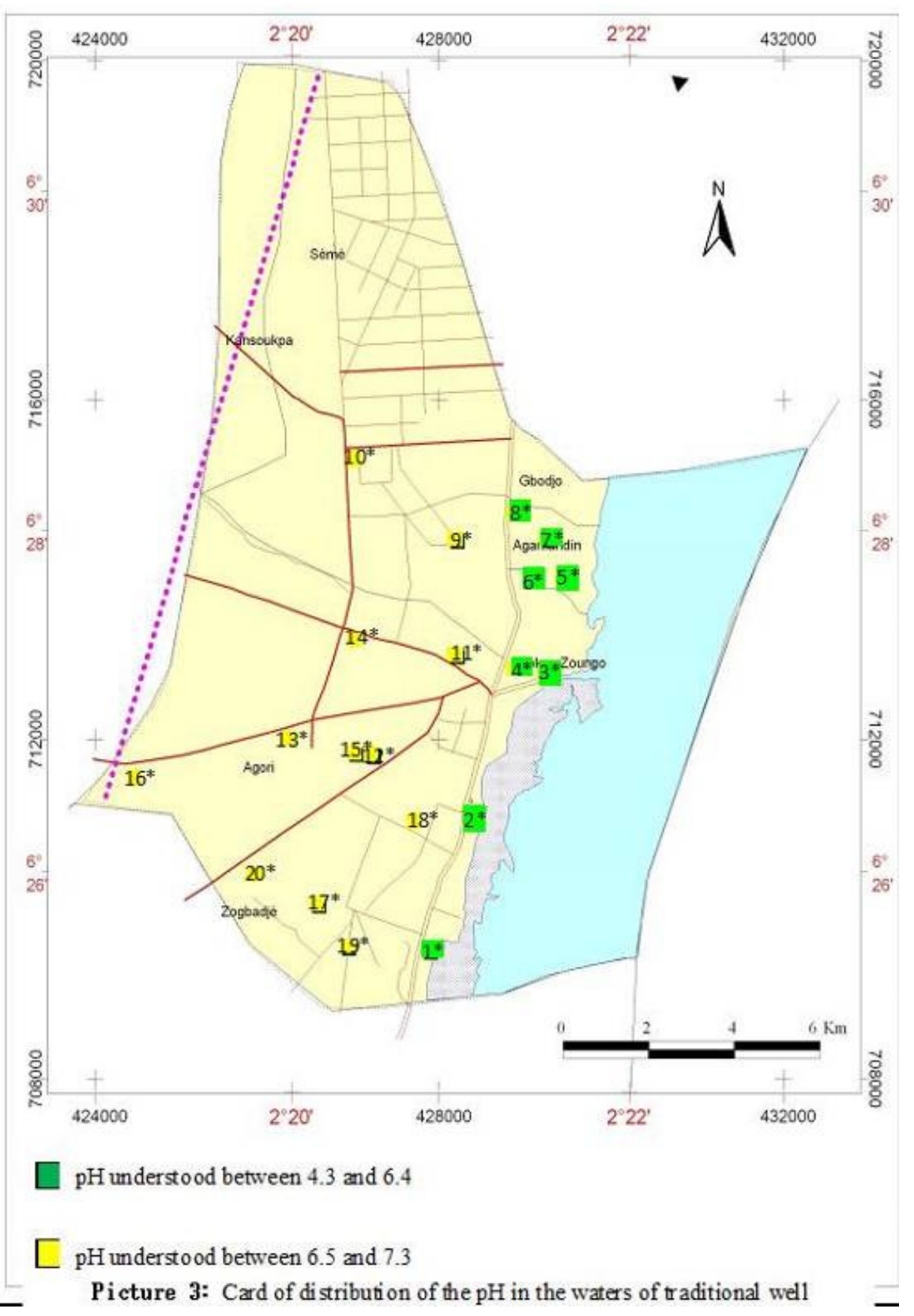

ELECTRIC CONDUCTIVITY: It permits to appreciate the degree of water mineralization. Its variation permits to follow the evolution of a chemical pollution (Degbey, 2004). The measure of conductivity permits to value quickly but roughly the global mineralization of water. The French Law gives the following indications on the relation existing between mineralization and conductivity (Rodier, 1978; Bossou, 2002).

Conductivity <100 $\mu \mathrm{s} / \mathrm{cms}$ : Very weak Mineralization. $100 \mu \mathrm{s} / \mathrm{cm}<$ conductivity $<200 \mu \mathrm{s} / \mathrm{cm}$ : Moderate Mineralization.

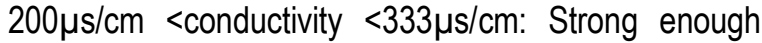
Mineralization.

$333 \mu \mathrm{s} / \mathrm{cm} \quad<$ conductivity $<666 \mu \mathrm{s} / \mathrm{cm}$ : Strong Mineralization.

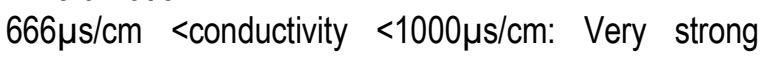
mineralization.

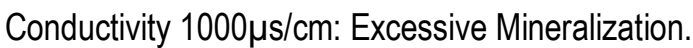

Water destined to consumption must have conductivity lower than $250 \mu \mathrm{s} / \mathrm{cm}$ (Guideline of the Union European of the $03 / 11 / 98$ ). 
Hounsinou et al.. J. Appl. Biosci. Survey and cartography of the spatial variation of the pollution of the waters from well of some districts of the township of Abomey-Calavi, Benin.

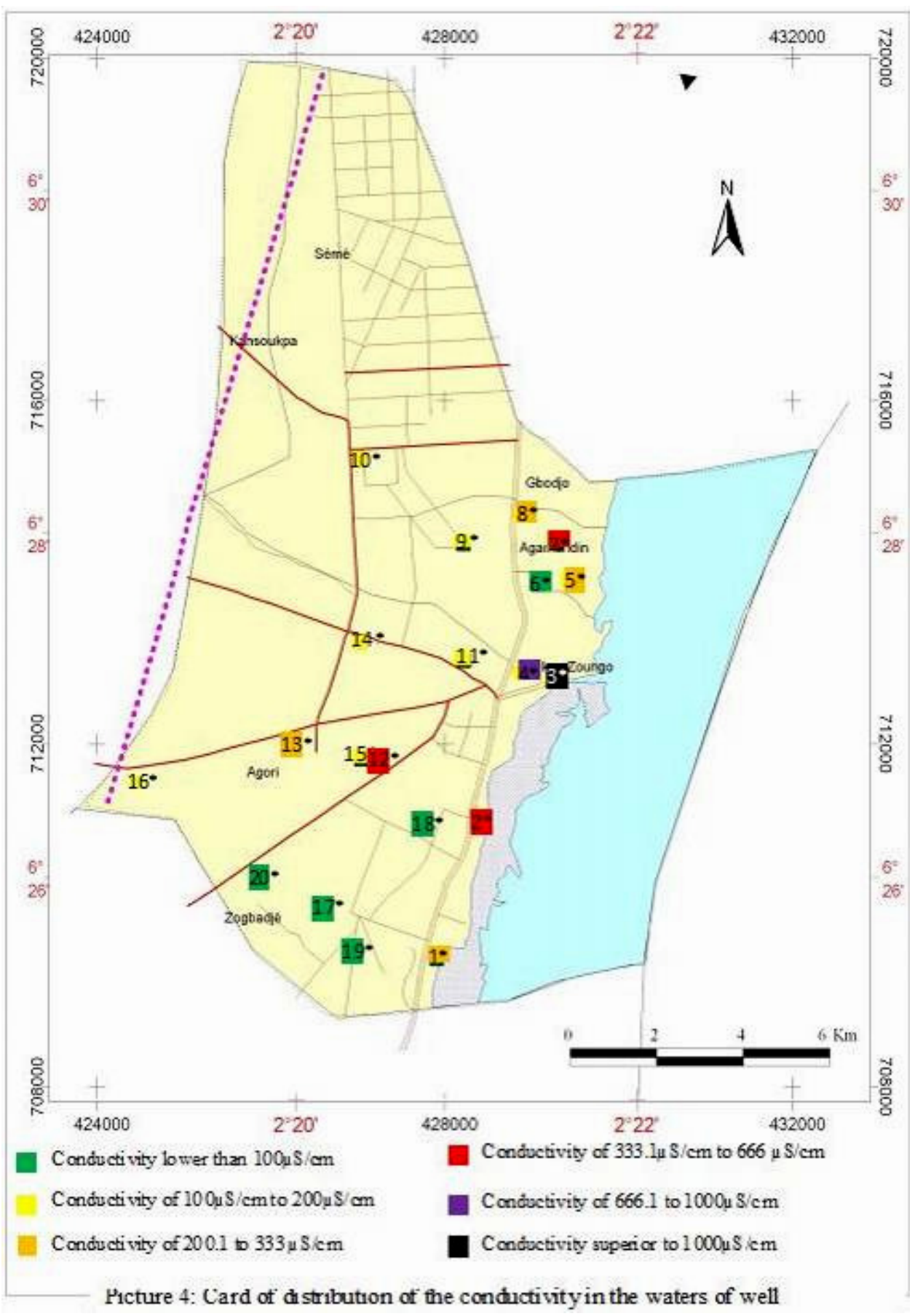

$60 \%$ of the studied well waters have conductivity compliant to the norms of the European Union. The conductivity of the waters of well analyzed varies from $66.8 \mu \mathrm{s} / \mathrm{cm}$ to $1128 \mu \mathrm{s} / \mathrm{cm}$. $25 \%$ of these waters have a very weak mineralization; $30 \%$ have a moderate mineralization; $20 \%$ have a strong enough mineralization, $15 \%$ have a strong mineralization, $5 \%$ have a very strong mineralization and $5 \%$ of these waters have an excessive mineralization. All wells moved away relatively from the Nokoue Lake (well $n^{\circ}$ 9 to 20 ) but the well ${ }^{\circ} 17$ have conductivity compliant to the norms of the European Union. Most nearest wells of the lake (Well $n^{\circ} 2,3,4,5,7$ and 8) have a conductivity passing the norms of the WHO and the European Union. These last wells are polluted by the Nokoué lake that is mineralized very excessively (equal 

waters from well of some districts of the township of Abomey-Calavi, Benin.

conductivity to $9000 \mu \mathrm{s} / \mathrm{cm}$ on average). The wells near of the lake are the wells the more mineralized and less mineralized than the lake because the water of the lake very loaded of minerals nourishes these wells but at the time of the passage of the water of the lake toward the wells, according to the crossed rocks and the depth of the wells, the water of the lake is filtered and is ridded of a part of these minerals.

TOTAL DISSOLVED SOLIDS (TDS): It is essentially about the strong minerals in water: calcium, magnesium, sodium, bicarbonates, chlorides and sulphates; they confer to water his/her/its taste (DEGBEY, 2004). The TDS informs on the mineralization of water. The saltiness of waters can also be represented by the TDS that corresponds to the sum of the concentrations of the major chemical elements $\left(\mathrm{Ca}^{2+}, \mathrm{Na}, \mathrm{Mg}, \mathrm{K}, \mathrm{Cl}, \mathrm{SO}_{4}, \mathrm{NO}_{3}, \mathrm{HCO}_{3}\right)$ (GOMEZ, 2009). The conductivity is bound to the concentration of all ions in the solution: major ions and minor ions (often the nitrites, iron, ions ammonium, fluorine, lead...). The minor elements are appreciated in relation to the weak concentration of their content in waters. The conductivity essentially depends therefore on the major chemical elements of the TDS. Thanks to the software SPSS (Statistical Package for Social Science) the coefficient of interrelationships between the physical and chemical parameters of the waters of well analyzed was calculated. The saltiness is bound strongly to the conductivity (0.893) and to the TDS (0.894). The TDS is perfectly bound to the conductivity (1.000). For all wells that we studied, the TDS (in $\mathrm{mg} / \mathrm{L}$ ) measured is equal at 0.56 times the conductivity (in $\mu \mathrm{s} / \mathrm{cm}$ ) measured. The card of distribution of the TDS in the studied wells is superimposable to the card of distribution of the conductivity in these wells. The TDS of the studied well water varies from $37 \mathrm{mg} / \mathrm{L}$ to 632 $\mathrm{mg} / \mathrm{L}$. 
Hounsinou et al.. J. Appl. Biosci. Survey and cartography of the spatial variation of the pollution of the waters from well of some districts of the township of Abomey-Calavi, Benin.

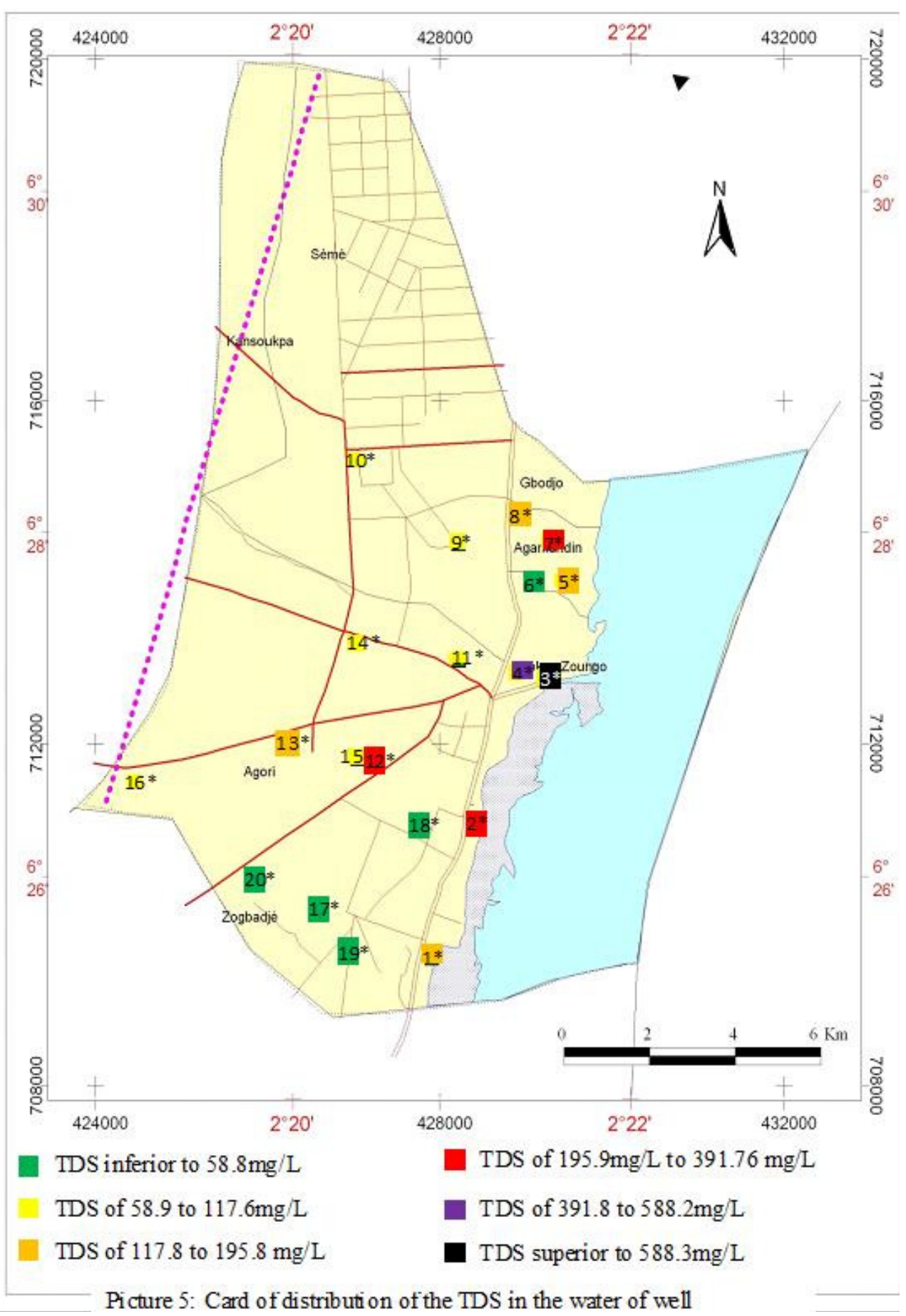

TURBIDITY : The turbidity of water is caused by the presence of substances that are suspended in water, for example: the clay, the silts, the colloidal organic particles, the plankton and of other microscopic organisms (DEGBEY, 2004). When the turbidity is lower in $5 \mathrm{FNU}$, Water is clean. When it is understood between 5 and $30 \mathrm{FNU}$, water is slightly troubled and when the turbidity is superior in $50 \mathrm{FNU}$, water is troubled (GOMEZ, 2009). When the turbidity is raised, water is colored. According to the norms of Benin of February $20^{\text {th }} 2011$, the turbidity of water destined to the consumption must be lower or equal to $5 \mathrm{FNU}$. 

waters from well of some districts of the township of Abomey-Calavi, Benin.

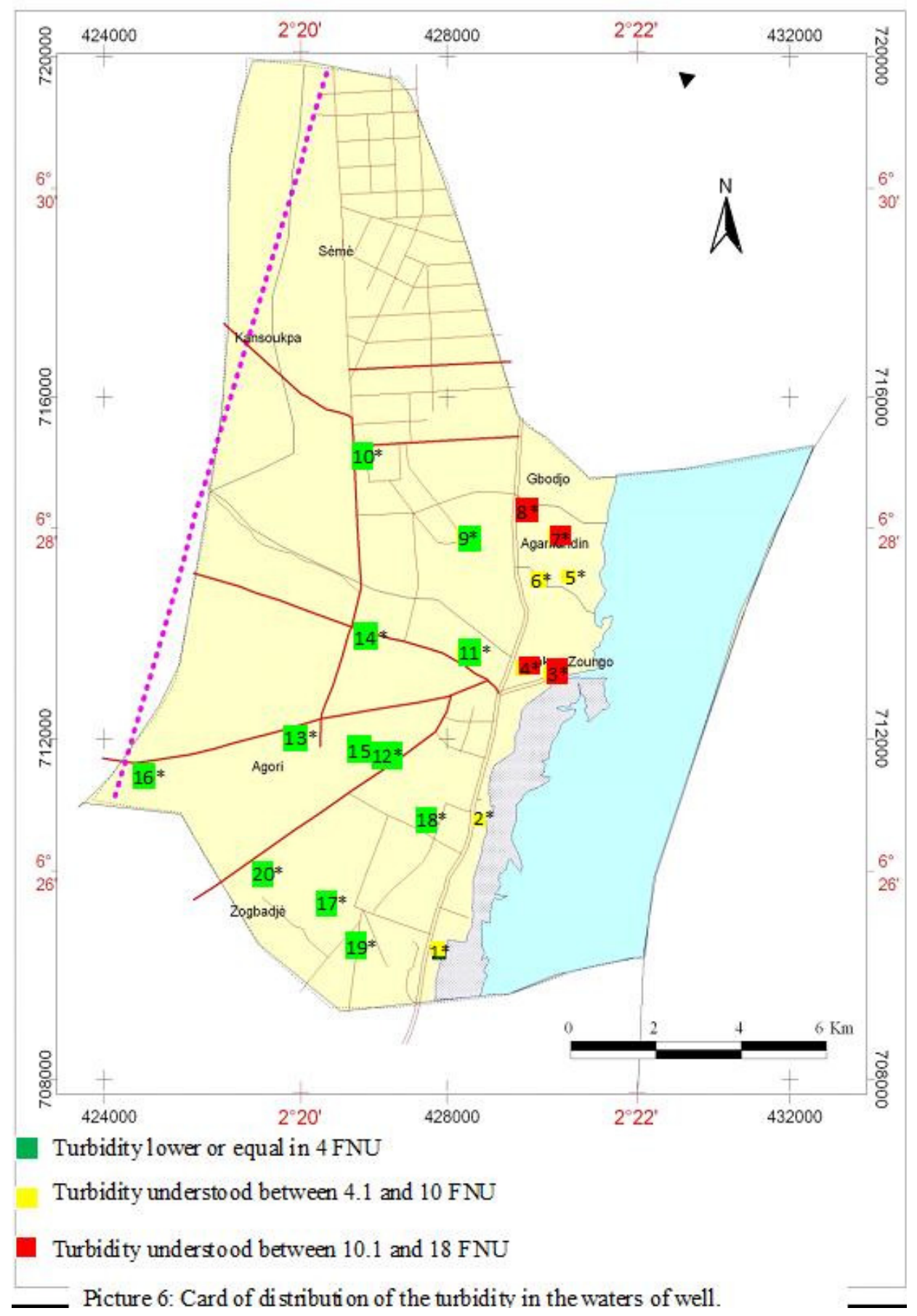

$65 \%$ of the studied wells have turbidity compliant to the Beninese norms for a drinking water. The turbidity of the waters of well analyzed varies from 1 to $18 \mathrm{FNU}$. All wells moved away relatively from the Nokoué lake (well $n^{\circ} 9$ to 20 ) have more lucid waters (turbidity 4 FNU) that the rainwater meteoroid (turbidity $=9 \mathrm{FNU}$ ): Soil filters the waters of infiltration. The waters of the wells near of the lake (well $n^{\circ} 1$ to 8 ) are slightly troubled (4 FNU
$<$ turbidity $18 \mathrm{FNU}$ ). These last wells are polluted by the Nokoué lake that is troubled (equal turbidity in 55.5 FNU about) and colourful. These wells are slightly troubled because the water of the lake charged of matters in abeyance nourishes these wells; but at the time of the passage of the water of the lake toward the wells, water is filtered by the rocks and ridded of a part of the substances and matters. The wells 3 and 4 have 
Hounsinou et al.. J. Appl. Biosci. Survey and cartography of the spatial variation of the pollution of the waters from well of some districts of the township of Abomey-Calavi, Benin.

an elevated turbidity (18 and 14 FNU) because, downstream these wells, the lake is disturbed by the human activities. These places are the ambarcadaires where one unloads some dugouts, the fished fishes and of the contraband gas and a part of these products is poured in the lake. The turbidity of the wells $n^{\circ} 7$ and 8 are raised (17 and 14 FNU) because of the same commercial exchanges downstream these wells in the lake.

POTENTIAL REDOX: According to the matrix of interrelationship (picture 16) the potential redox is bound greatly and vice versa to the $\mathrm{pH}(-0.892)$ and to the turbidity $(-0.758)$.

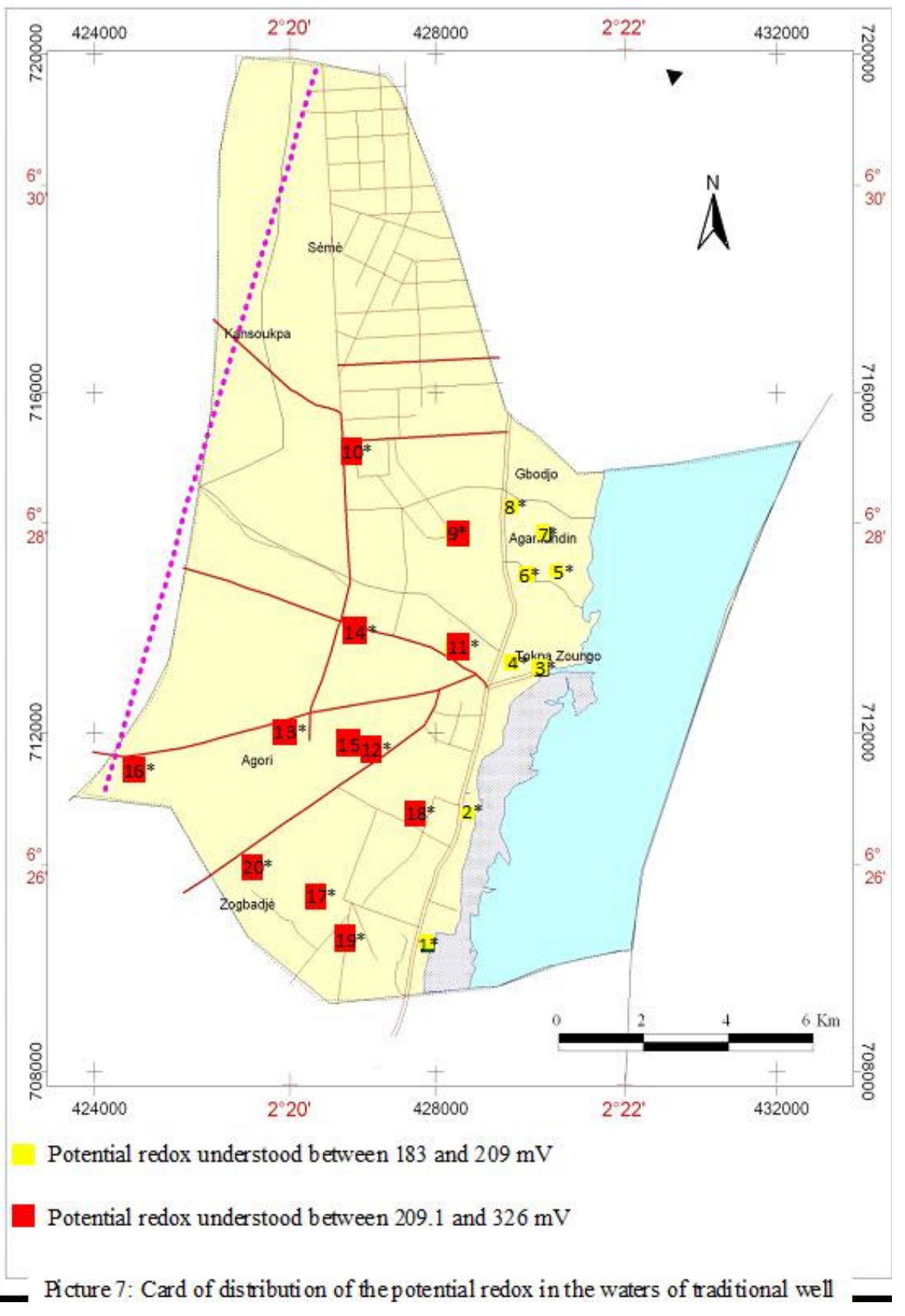

The potential redox of the studied well waters varies wells moved away of the lake (well $n^{\circ} 9$ to 20) is from $183 \mathrm{mV}$ to $326 \mathrm{mV}$. The potential redox of the superior to the potential redox of the wells near of the 

waters from well of some districts of the township of Abomey-Calavi, Benin.

lake (well $n^{\circ} 1$ to 8 ) that is superior to the potential redox of the water of the lake. On the other hand the turbidity and the $\mathrm{pH}$ of the waters of the wells moved away of the lake are lower to those of the wells near of the lake. So, contrary to the turbidity and to the $\mathrm{pH}$, the potential redox of the waters of the wells moved away of the lake is raised more than the one of the wells near of the lake it is because the potential redox is bound greatly and vice versa to the turbidity and to the $\mathrm{pH}$.
LEAD: Lead is a poisonous substance. The presence of lead in the underground water can come from a contamination by a water of surface or can come from soil. Lead is naturally present in soil in height of a few score of soil mg/kg (BOSSOU, 2002). According to the instructions of the European Union of the $03 / 11 / 98$ for a drinking water, the content made of lead of consumption water must not exceed $50 \mu \mathrm{g} / \mathrm{L}$.

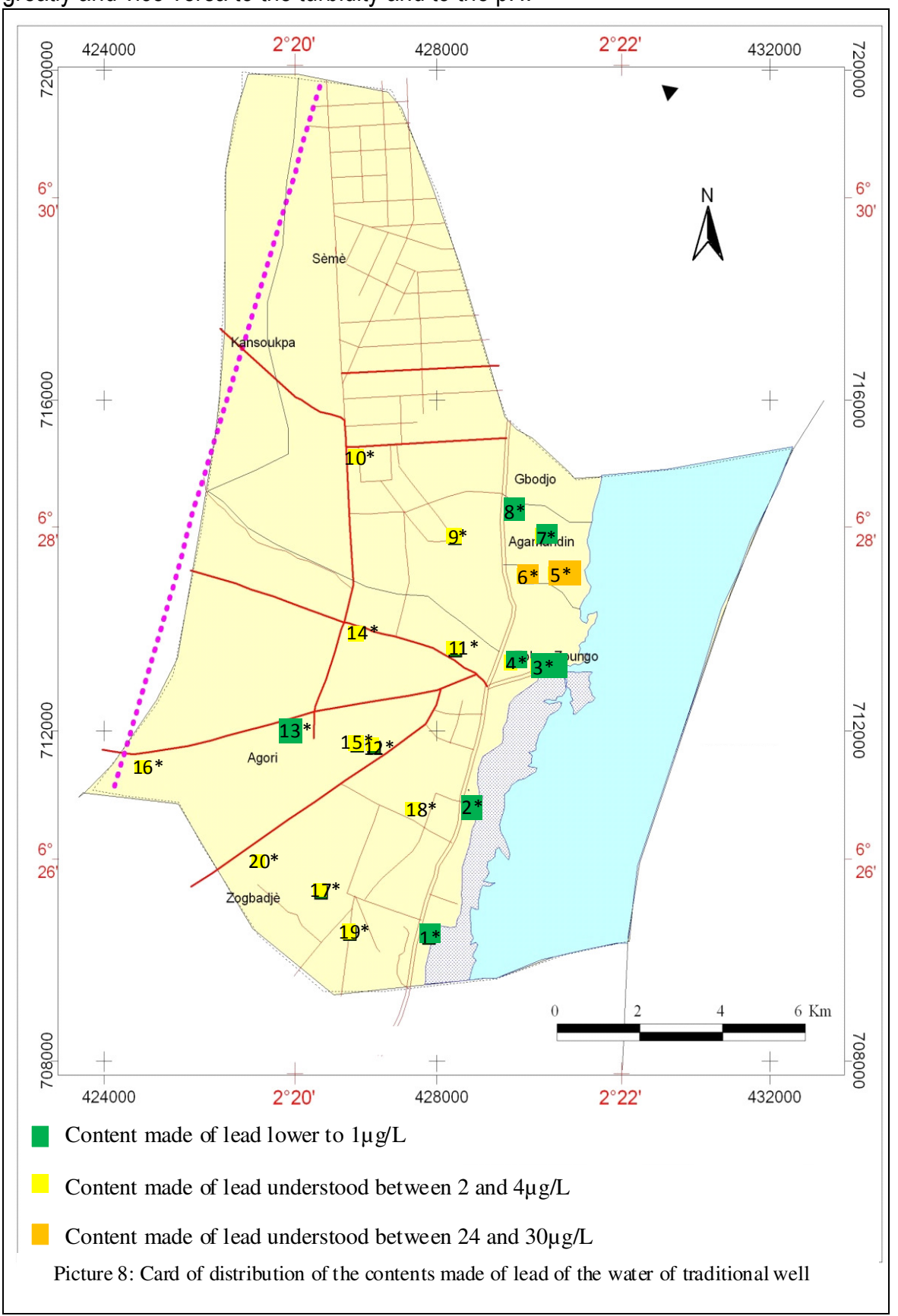



waters from well of some districts of the township of Abomey-Calavi, Benin.

All studied well waters have contents made of lead conform to the norms of the union European. The content made of lead of these waters varies from 0 in $30 \mu \mathrm{g} / \mathrm{L}$. the waters of the wells relatively moved away of the lake (well $n^{\circ} 9$ to 20) but the well $n^{\circ} 13$ have a content made of lead understood between 2 and 4 $\mu \mathrm{g} / \mathrm{L}$. This weak pollution comes from soil. In general, the waters of the wells near of the lake have a weaker content made of lead. This very weak pollution has for origin the lake that with its waters poor in lead diluted the waters of these wells with regard to lead.
ZINC: Zinc is an undesirable substance in water. The presence of zinc in the underground water can come from a contamination by the waters of surface or can come from soil. Zinc is naturally present in soil. It is more abundant than lead in the terrestrial crust. According to instructions of the European Union of the 03/11/98 for a drinking water, the content made of zinc of water destined to the consumption must exceed $5 \mathrm{mg} / \mathrm{L}$.

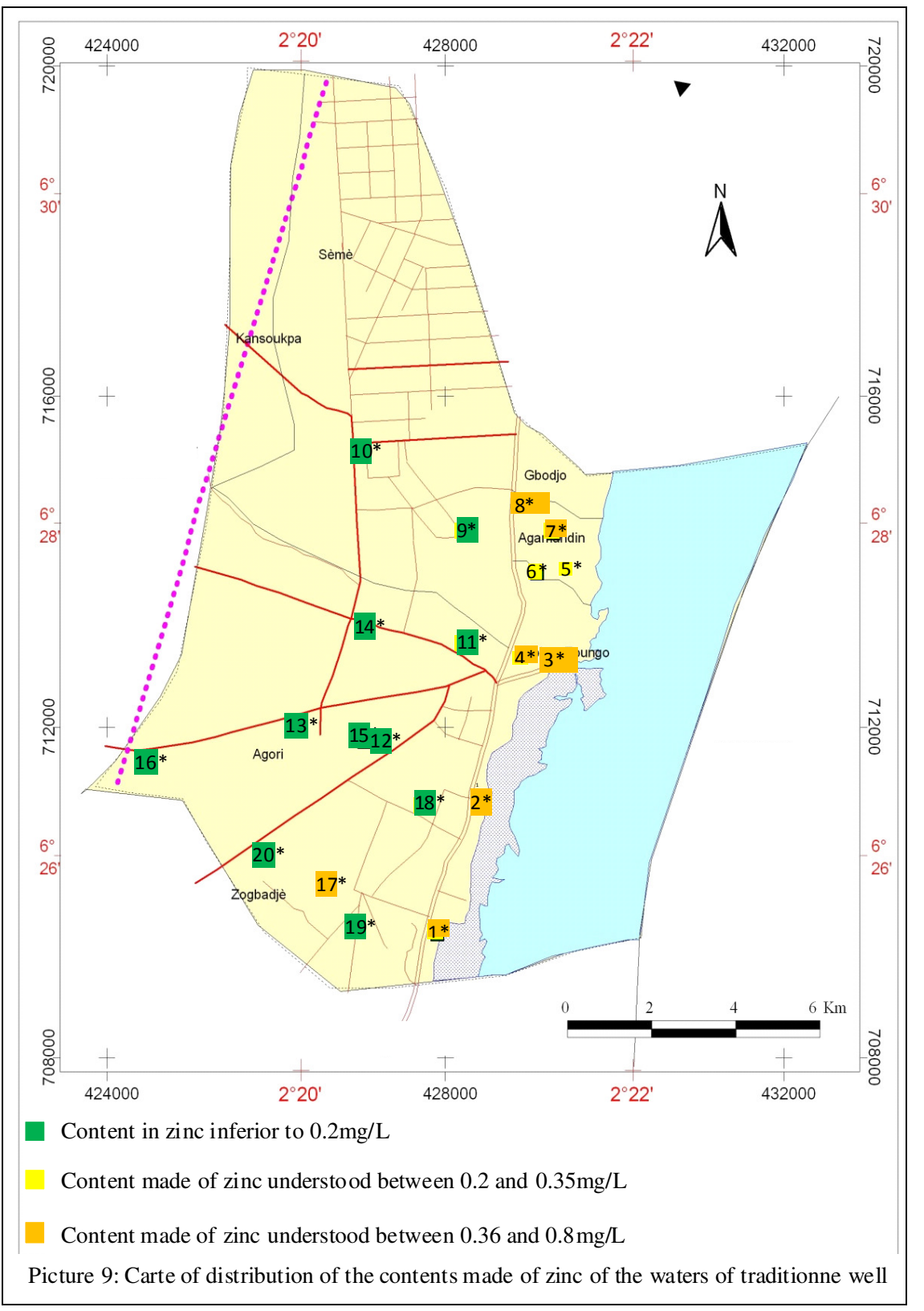




\section{Hounsinou et al.. J. Appl. Biosci. Survey and cartography of the spatial variation of the pollution of the}

waters from well of some districts of the township of Abomey-Calavi, Benin.

All studied well waters have contents made of zinc conform to the norms of the European Union. The content made of zinc of these waters varies from 0 to $0.8 \mathrm{mg} / \mathrm{L}$. The waters of the wells relatively moved away of the lake (well $n^{\circ} 9$ to 20 ) but the well $n^{\circ} 17$ have a weak content made of zinc (lower to $0.2 \mathrm{mg} / \mathrm{L}$ ). This weak pollution comes from soil. The waters of the wells near of the lake have a content made of more elevated zinc (enters 0.2 and $0.8 \mathrm{mg} / \mathrm{L}$ ) with an average of 0.46 $\mathrm{mg} / \mathrm{L}$ that is as equal to the average of the contents made of zinc in the waters of the lake. This, not only confirms that the waters of the lake nourish the wells near of the lake but watch that at the time of the passage of the water of the lake toward the wells, ions zinc is not filtered by soil. The cards of distribution of the physical and chemical parameters that we have just presented put in inscription the pollution of the waters of attributable well to soil and the extent of the pollution of the wells (well $n^{\circ} 1$ to 8 ) by the Nokoue lake. Some physical parameters measured have neighbouring values for all wells. It is about the temperature, of the dissolved oxygen and of the percentage of oxygen saturation. The presence of the lake did not influence these parameters to the level of the wells near of it. The temperature varies from 26.2 to $26.9^{\circ} \mathrm{C}$ in the studied wells. The oxygen dissolves and the percentage of oxygen saturation varies respectively from 1.83 to 2.87 $\mathrm{mg} / \mathrm{L}$ and 22.3 to $35.1 \%$. According to the Moroccan Norm NM, 03.7.001 of the oxygen dissolved in a water of consumption must be consistent between 5 and $8 \mathrm{mg} / \mathrm{L}$. All waters of well-analyzed have some contents below the lower doorstep of the Moroccan Norm. Nevertheless, most present bacteria in the faecal matters are anaerobic optional, so that, the dissolved oxygen, in weak concentration in the studied well waters, influence very little their survival in soil. It is agreed to underline that a water of temperature situated between 25 and $28^{\circ} \mathrm{C}$ constitutes a middle of culture for microorganisms of the environment (Makoutodé et al, 1999; Gomez, 2009). The temperatures of waters sampled create a milieu favourable to the microbial development activity.

\section{RESULTS AND MICROBIOLOGICAL PARAMETER INTERPRETATIONS}

A certain number of bacterial species normally absent from a person's intestine in good health, can be secreted in an intermittent way and in variable quantity according to the place and the state of health of the population. These pathogenic, or potentially pathogenic bacteria, are responsible for most infectious illnesses that rage in subtropical Africa: cholera, typhoid fever, dysentery, gastroenteritis, diarrhoea,...Generally transmitted to mankind by digestive way bound to the consumption of water or food contaminated, the pathogenic bacteria play a determining role in biological pollution of table water from a latrine (BOSSOU, 2002). The pathogenic bacteria are not always omnipresent in the faecal matters contrary to the indicatory bacteria of the faecal pollution. It would be an illusion to base the tests of faecal contamination solely on the systematic research of pathogenic bacteria species. The best approach consists in a research of the indicatory bacteria of the faecal pollution, completed by a possible research of specific pathogenic germs

BANAL GERMS: The first microbiological parameters that we measured, for every sample, are the banal germs. Water cannot contain any germs; it is said very healthy or very pure then. In the case where a water of well contains some, it must contain to the maximum of 50 germs $/ \mathrm{mL}$ (norms of Benin). Water is qualified of healthy and one can consume it. Beyond this value, water is suspected and it is necessary to search for in water the indicatory bacteria of the faecal pollution. 

waters from well of some districts of the township of Abomey-Calavi, Benin.

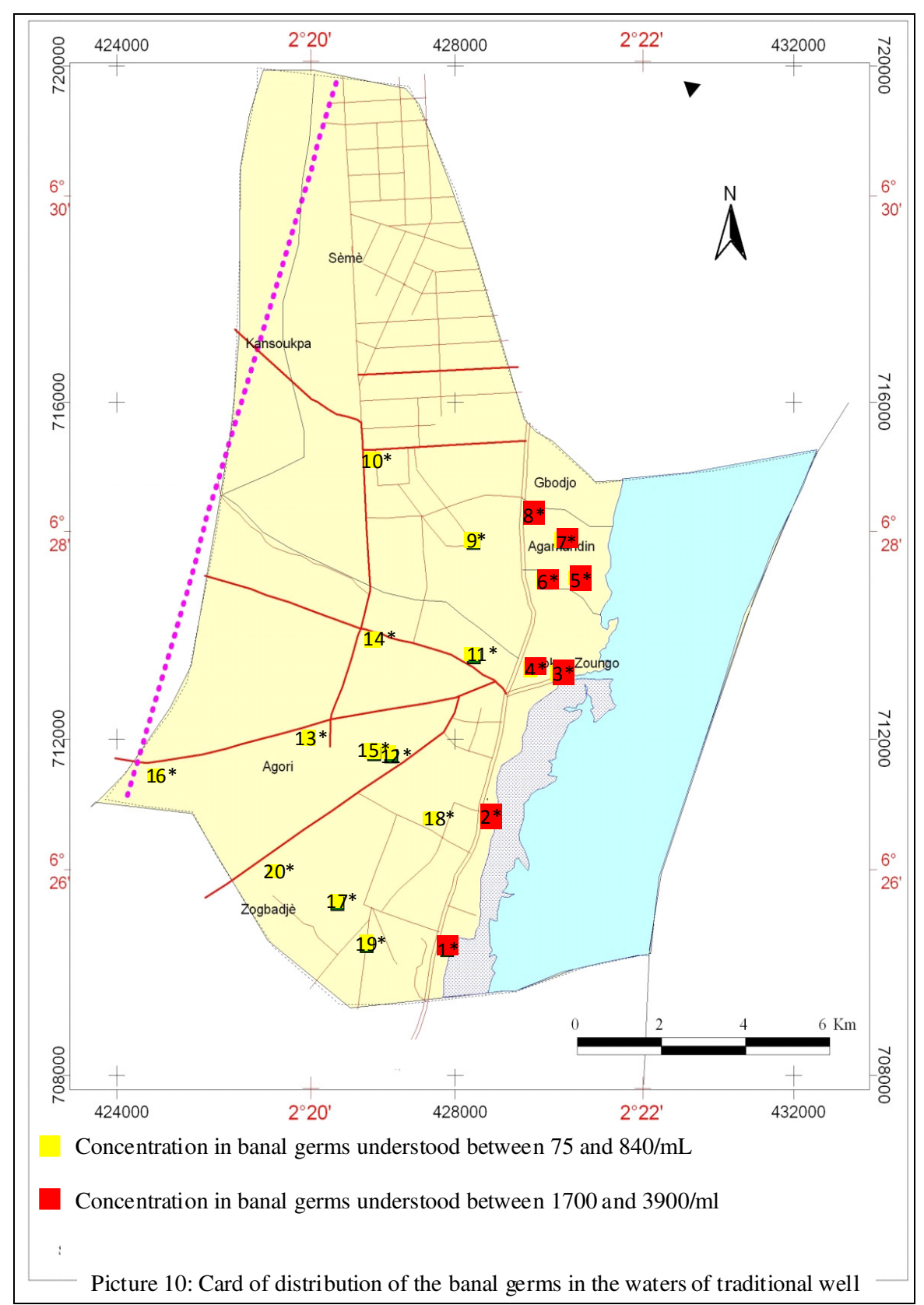

The concentration in banal germs of the waters of well analyzed varies 75 to $3.910^{3}$ by $\mathrm{ml}$ of water. All these waters are not compliant to the norms of Benin for a drinking water. The waters of well near of the lake (well $\mathrm{n}^{\circ} 1$ to 8 ) contain several times more of banal germs in relation to the well moved away of the lake (well $n^{\circ} 9$ to 20). As the cards of distribution of the physical and chemical parameters presented, the card of distribution of the banal germs permits to identify the wells whose pollution is influenced by the waters of the lake. All waters of well analyzed are suspected (more than 50 banal germs by $\mathrm{ml}$ of water). It is why for the indicatory bacteria of faecal pollution (total coliforms, coliforms thermotolerants, Escherichia coli and intestinal enterococci) were searched.

TOTAL COLIFORMS: The group of the coliforms consists of the bacteria belonging to the family of the Enterobacteriaceaces and makes to two entities appear. The coliforms of faecal origin or coliforms thermotolerants hosts of the digestive tube of the man and animals warm-blooded; the other of non-faecal origin, is part of the aquatic bacterial communities 
Hounsinou et al.. J. Appl. Biosci. Survey and cartography of the spatial variation of the pollution of the waters from well of some districts of the township of Abomey-Calavi, Benin.

(comes of the infiltration waters) or telluric (comes of

WHO. Not all waters of the wells studied are compliant the earth). A drinking water must not contain any total to the norms of the WHO for a drinking water. coliforms $(0 / 100 \mathrm{ml})$ according to the norms of the

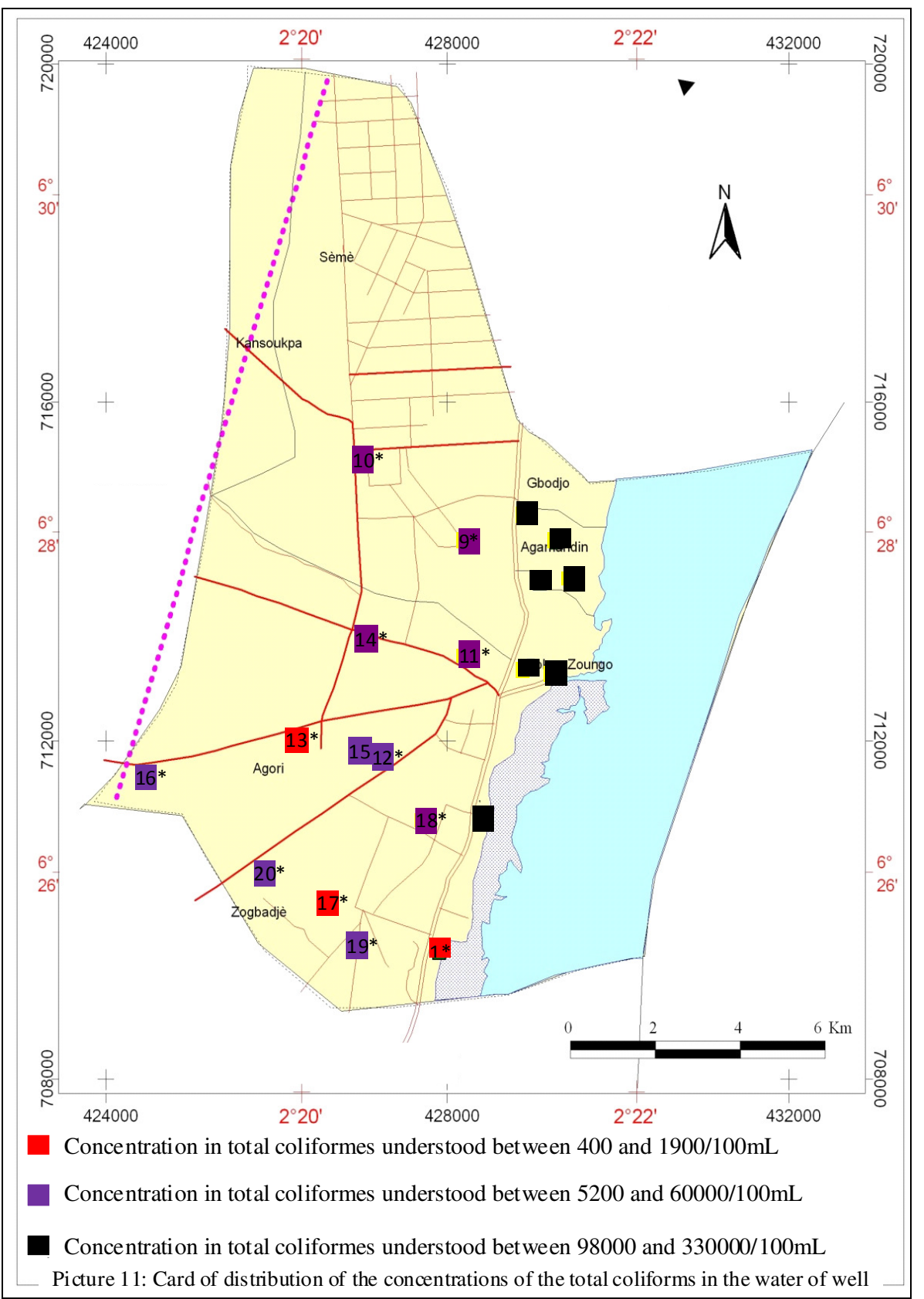

The concentration of these waters in total coliforms varies from 400 to $3.310^{5}$ in $100 \mathrm{~mL}$ water. The waters of most wells near of the Nokoué lake (well $n^{\circ} 2$ to 8 ) are polluted excessively by the total coliforms (enters $9.810^{4}$ and $3.310^{5}$ in $100 \mathrm{~mL}$ ). All waters of the wells relatively moved away of the lake are less contaminated. They contain less than $610^{4}$ total coliforms in $100 \mathrm{~mL}$ water. The reasons of contamination of these waters of well are numerous: - Insufficiency of purification works inefficiency of the protective devices of the wells and lack of hygiene around the wells.

-The non-tightness of the wells and latrines. 


\section{Hounsinou et al.. J. Appl. Biosci. Survey and cartography of the spatial variation of the pollution of the}

waters from well of some districts of the township of Abomey-Calavi, Benin.

-Not only the table water of weak depth (especially very close to lake) communicates with the content of the latrines that loads the waters of well of coliforms thermotolerants but also, this weak depth of the tablecloth makes easy and fast the acquirement of other total coliforms by the waters of well from the waters of infiltration. The near well waters contain a lot more total coliforms than those of the distant wells in general because the risks of contamination are distinctly more elevated to the level of the wells near of the lake. Broadly speaking the concentration in total coliforms varies appreciably from a well to the other because these risks of contamination vary from a well to the other. We recall that the pathogenic bacteria where potentially pathogenic responsible most infectious illnesses that rage in subtropical Africa are of faecal origin. The research of coliforms thermotolerants (one coins group of the total coliforms) mainly of faecal origin will indicate if these waters are inheritable to contain pathogenic germs.

COLIFORMS THERMOTOLERANTS: The species the more frequently associated to this bacterial group is the Coli Escherichia and in a least measure, some species of the Citrobacter kind, Enterobacters and Klebsiellas (Elmund et al, 1999; Canada health, 1991; Edbery et al, 2000; Gomez, 2009). The bacterium Escherichia Coli represents all time 80 to $90 \%$ of the coliforms thermotolerants detected (Edberg et al, 2000; Gomez, 2009). The interest of the detection of the coliforms thermotolerants, as indicatory organisms of faecal pollution, resides in the fact that their survival in the environment is generally equivalent to the one of the pathogenic bacteria and that their density is generally proportional to the degree of pollution produced by the faecal matters (CEAEQ, 2000; Gomez, 2009). According to the norms of the $\mathrm{WHO}$, water destined to the consumption must contain coliforms thermotolerants $(0 / 100 \mathrm{~mL})$. All the waters from the wells analyzed contain some coliforms thermotolerants and are not compliant to the norms of the WHO. The concentration in coliforms thermotolerants of these waters of well varies from 20 to $910^{4}$ in $100 \mathrm{~mL}$ water. All waters of the wells near of the lake (well $n^{\circ} 1$ to 8 ) have some concentrations in coliforms thermotolerants understood between $710^{3}$ and $910^{4} / 100 \mathrm{~mL}$ water. The waters of the wells moved away of the lake (well $n^{\circ} 9$ to 20) are all less polluted by the coliforms thermotolerants because the risks of contaminations enumerated previously are less elevated for these wells. Although the presence of coliforms faecal thermotolerants usually reveals a faecal origin contamination, several faecal coliforms is not of faecal origin. They can come from waters enriched in organic matter, like the industrial sewages of the sector of the doughs and papers or of the food transformation (WHO, 2000; Gomez, 2007). It is why it is appropriated more to use the term generic "coliforms thermotolerants" rather than the one of "faecal coliforms" (WHO, 1994; Robertson, 1995; Gomez, 2009). Only the Escherichia coli, a species belonging to the coliforms thermotolerants is a specific indicator of a faecal contamination and his/her/its presence indicates the presence possible of microorganisms pathogenic enteric.

ESCHERICHIA COLI: The Escherichia coli are a bacterial species belonging to the group of the coliforms thermotolerants themselves belonging to the group of total coliforms. The Escherichia Coli are very abundant in the human and animal intestinal flora and it is the only species that either strictly of faecal origin. Their presence in water means that this last is contaminated by faecal origin pollution and that it can contain pathogenic microorganisms therefore (French Ministry lasting Development of the environment and Parks, 2012). According to the norms of the WHO, water destined to the human consumption must contain some Escherichia Coli $(0 / 100 \mathrm{~mL})$. 

waters from well of some districts of the township of Abomey-Calavi, Benin.

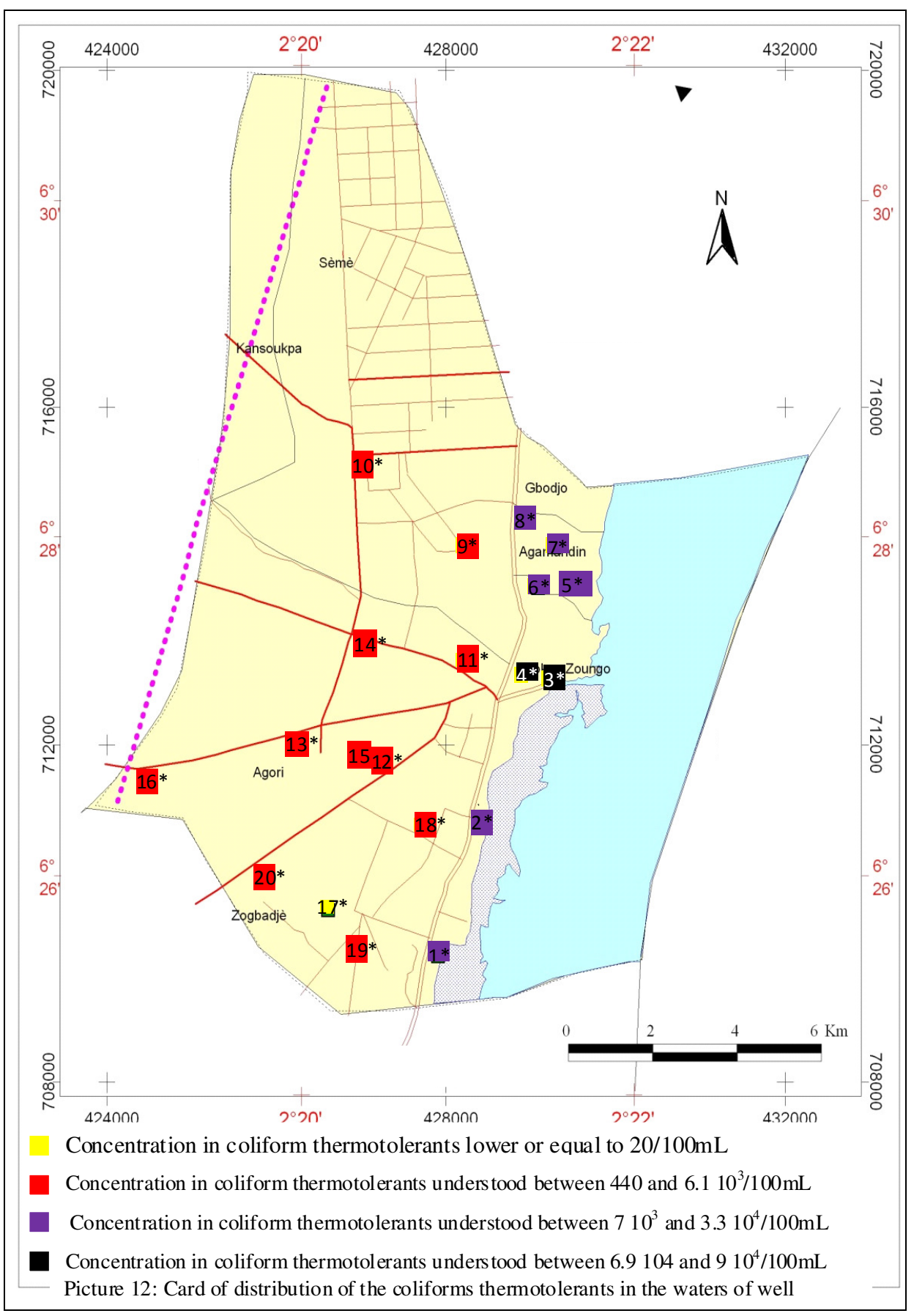



waters from well of some districts of the township of Abomey-Calavi, Benin.

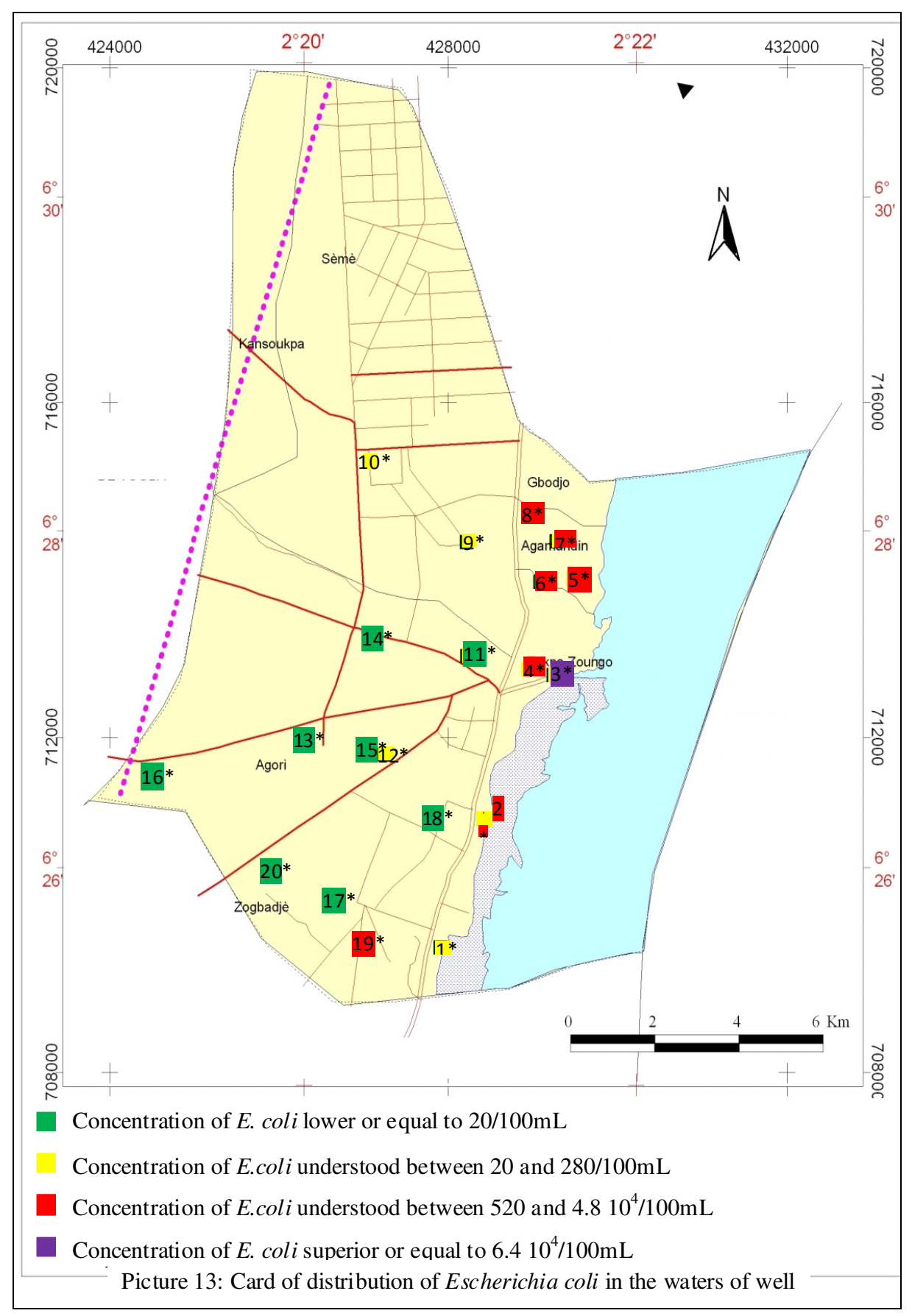

$40 \%$ of the studied wells did not contain Escherichia coli. The concentration of Escherichia coli in the rest of the wells varies from 20 to $6.410^{4}$ in $100 \mathrm{~mL}$ water. In $100 \mathrm{~mL}$ water of each of the studied wells, there is less Escherichia coli than of coliforms thermotolerants and less coliforms thermotolerants that of total coliforms. It proves a consistency in the results because the Escherichia coli is a species belonging to the subgroup of the coliforms thermotolerants and these last belonging to the group of the total coliforms. All waters of the wells situated the Nokoué lake very close to (well $\mathrm{n}^{\circ} 1$ to 8 ) are contaminated by the Escherichia Coli with concentrations generally very elevated and only the third of the waters of the wells moved away of the lake (well $n^{\circ} 9,10,12$ and 19) are contaminated by the Escherichia coli with less elevated concentrations. These containing waters of the Escherichia Coli are contaminated therefore by the faecal matter capable to 

Hounsinou et al.. J. Appl. Biosci. Survey and cartography of the spatial variation of the pollution of the
waters from well of some districts of the township of Abomey-Calavi, Benin.

contain pathogenic germs. To identify to the level of each of the wells concerned if the faecal pollution is of human or animal type, in addition to the concentrations of the coliforms thermotolerants the concentrations of the intestinal enterococci in these waters is necessary. INTESTINAL ENTEROCOCCIS: The group of intestinal enterococci consists of faecal and non-faecal origin species (plant, bugs, soil) that one cannot discern with the help of the simple tests. In addition, the intestinal enterococci are not of good indicators of the faecal pollution. However, considering their strong resistance and their inability to increase in the aquatic environment, the intestinal enterococcus can be used like indicators of the pathogenic bacteria (that increase little in the aquatic environment) and of the viruses (that survive longer in aquatic environment that the coliforms thermotolerants) (LECLERC and MOSSEL, 1989; BOSSOU, 2002). According to the norms of the WHO, a drinking water must not contain any intestinal enterococci.

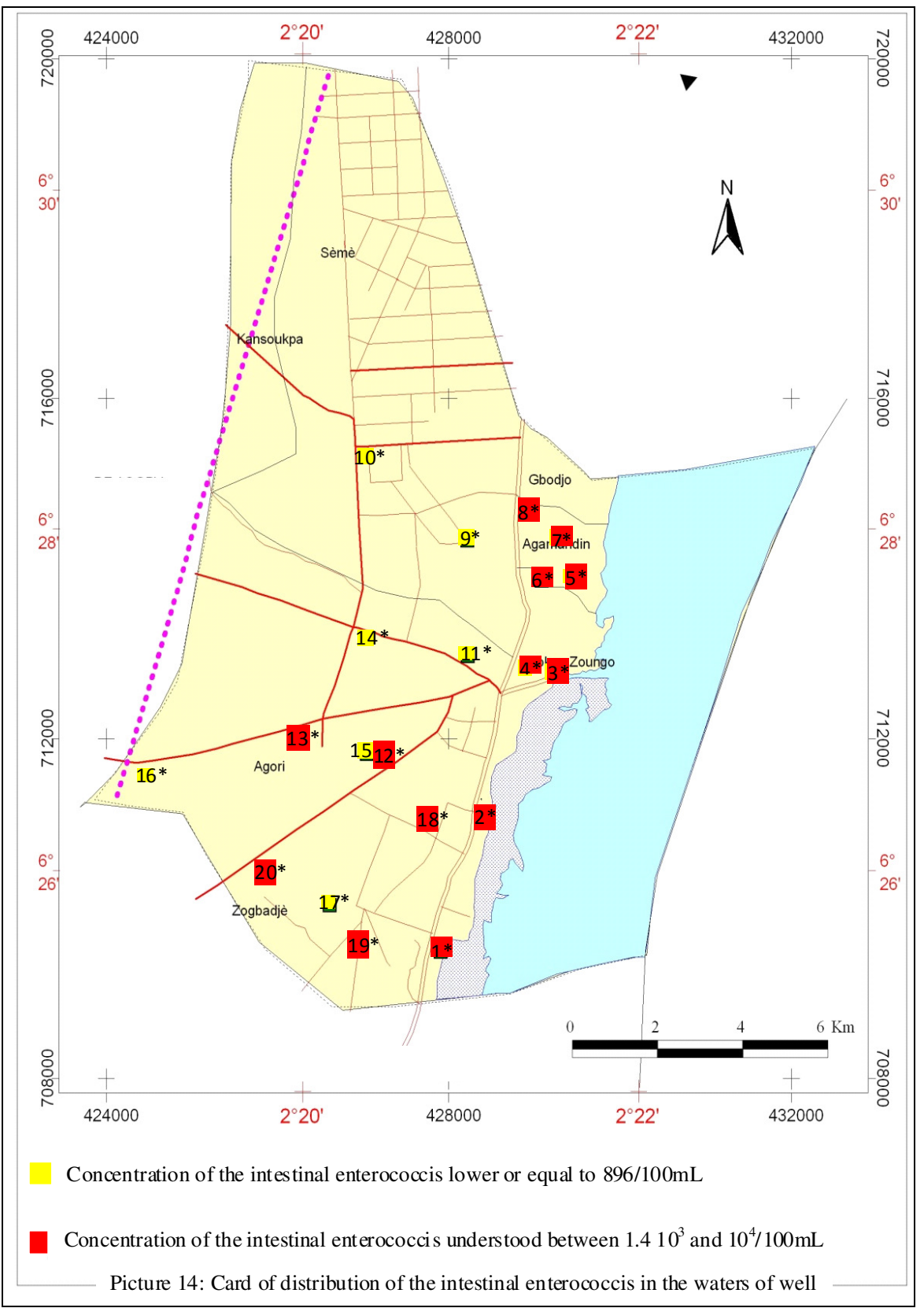


Hounsinou et al.. J. Appl. Biosci. Survey and cartography of the spatial variation of the pollution of the waters from well of some districts of the township of Abomey-Calavi, Benin.

All waters of well analyzed contain intestinal enterococci and are not therefore compliant to the norms of the WHO. The concentration in intestinal enterococci of these waters varies from 40 to $10^{4}$ in $100 \mathrm{~mL}$ water. The middle concentration in these enterococci of the waters of the wells near of the lake is raised more than the one of the wells moved away of this lake. The report coliforms thermotolerants / intestinal enterococci is generally superior to 4 in the human and lower faecal matters to 1 in the animal faecal matters. This property is used in the research of the intestinal enterococci to determine if the pollution (faecal) is of human or animal origin (Baba-Moussa, 1994; Bossou, 2002.

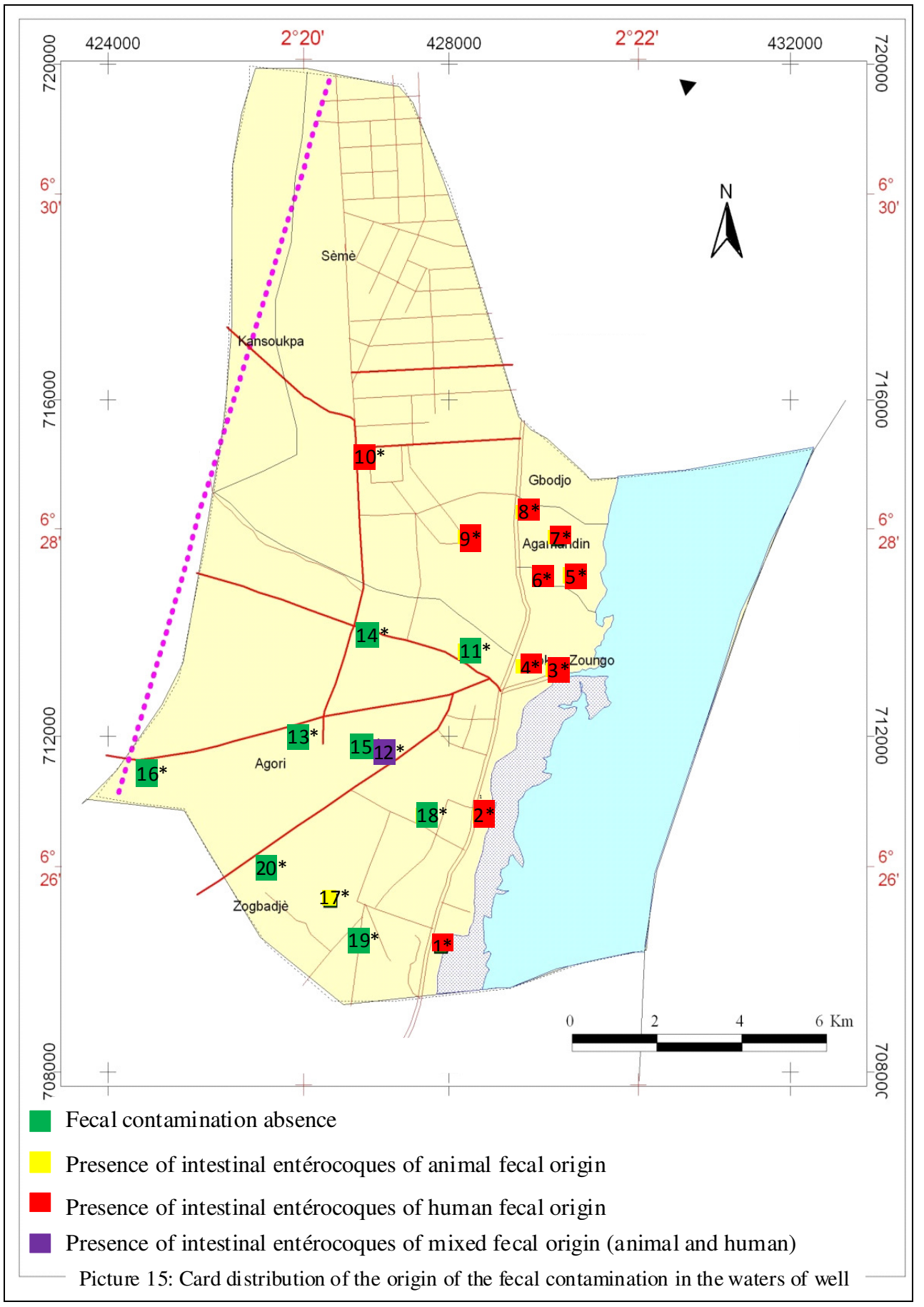




\section{Hounsinou et al.. J. Appl. Biosci. Survey and cartography of the spatial variation of the pollution of the waters from well of some districts of the township of Abomey-Calavi, Benin.}

$50 \%$ of the studied well waters are contaminated by the faecal matter of human origin. It is about all wells situated the lake very close to and of the wells $n^{\circ} 9$ and 10. $5 \%$ of the studied wells are contaminated by the faecal matter of animal origin (this well is situated to some meters of the site of raising of pigs of the Faculty of the Agronomic Sciences from the university of Abomey-Calavi to Benin) and $5 \%$ of the studied wells are contaminated by the faecal matter of mixed origin (animal and human). This work revealed that all studied well waters are much polluted and identify the human as the main person responsible of the bacteriological contamination of these waters. This work also permitted to note that the cards of distribution of the parameters measured in the wells reveal the extent of the part of the table water of which the level of pollution is influenced by the Nokoue Lake. The contrast is big between the values measured in the waters of well near of the lake and those measured in the waters of the wells moved away of the lake for the following parameters: pH, turbidity, potential redox, banal germs and coliforms thermotolerants.

Table 1: The contrast between the parameters values measured in the waters of well near of the lake and those measured in the waters of the wells moved away of the lake.

\begin{tabular}{l|c|c}
\hline Measured Parameters & well near of the lake: well $\mathbf{n}^{\circ} \mathbf{1}$ to $\mathbf{8}$ & well distant of the lake: well $^{\circ} \mathbf{9}$ to $\mathbf{2 0}$ \\
\hline $\mathrm{PH}$ & 6.5 à 7.2 & 4.3 à 6.4 \\
Turbidity & 5 à $18 \mathrm{FNU}$ & 1 to $4 \mathrm{FNU}$ \\
Potential redox & 183 à $209 \mathrm{mV}$ & 209 to $326 \mathrm{mV}$ \\
Banal germs & $1.710^{3}$ à $3.910^{3} / \mathrm{Ml}$ & 75 to $840 / \mathrm{mL}$ \\
coliforms thermotolerants & $710^{3}$ à $910^{4} / 100 \mathrm{Ml}$ & 20 à $6.110^{3} / 100 \mathrm{~mL}$ \\
\hline
\end{tabular}

If the proximity of the lake was beneficial with regard to the $\mathrm{pH}$ of the wells near of the lake that is compliant to the norms of the European Union, with regard to most measured parameters, the proximity of the lake is an aggravating factor of the pollution of the waters of well. The predominance of the human faecal contamination of these waters puts the accent on the fact that humankind is the main actor of the destruction of his environment and in particular the increasing deterioration of the water quality. Men and women fall sick, while drinking water contaminated by their own faecal matters. The roof is for years the apparition of a cholera epidemic in the zone of survey and that worsens with the passing of the time. These results confirm those gotten by EL HAISSOUFI et al in 2011 and must be the object of a media beating in order to allow the population concerned to take the measure of the danger, to take knowledge and especially to apply the palliative measures of which here are some: The

\section{CONCLUSION}

This work permitted to note that all waters of well of the survey zone are polluted on the plane physical and chemical and microbiological. In the physical and chemical area, the $\mathrm{pH}$, the electric conductivity and the turbidity are respectively compliant to the advisable norms in $40 \%, 60 \%$ and $65 \%$ of the waters of the wells analyzed. The contents made of lead and in zinc of these waters are compliant to the norms of the WHO. On the microbiological plan, all waters of well-analyzed respect of the at least $15 \mathrm{~m}$ distance recommended by the WHO that must separate the latrines of a well. Extend the network of purification to the whole zone of survey. Building of the protective devices of the wells. Respect the rules of hygiene around the wells, at the time of the withdrawal, the transportation and the storage of the consumption water. Insulated latrinesBuilt to replace the existing latrines currently in the zone of survey. Insulated-Render the lateral partitions intern some wells. The role of the government in the struggle against the proliferation of the illnesses related to water in the zone of survey is fundamental and must pass by: The Extension of the network of drinking water adduction. An adequate organization of the abduction of garbage. A depollution of the water plans of which the Nokoue lake. The transportation on this lake (contraband gas) and the fishing must be controlled and consistent.

are contaminated by the banal germs, the total coliforms, the coliforms thermotolerants and the intestinal enterococci. $60 \%$ of these waters are contaminated by the Escherichia Coli, a faecal contamination mainly of human origin. This work also permitted to note that the cards of distribution of the parameters permitted to surround the extent of the space of influence of the Nokoue lake on the pollution of the waters of well. 


\section{REFERENCES}

Agassounon D.T. Tchibozo Micheline, Alassane Abdoukarim, Mama Daouda, Ahanhanzo Corneille, Toukourou Fatiou et Agbangla Clément (2010). Contrôle des paramètres physico-chimiques des eaux en bouteilles vendues à Cotonou. Bulletin d'Informations de la SOACHIM; 007; 131 - 138

Alassane Abdoukarim, 2004. Étude hydrogéologique du continental terminal et des formations de la plaine littorale dans la région de Porto-Novo (sud du Bénin): identification des aquifères et vulnérabilité de la nappe superficielle. Thèse de doctorat de 3ème cycle, département de géologie, faculté des sciences et technique, Université CHEIKH ANTA DIOP de DAKAR.

Baba Moussa A., 1994. Étude de la pollution bactériologique de la nappe phréatique à partir d'une latrine en Afrique subéquatoriale. Thèse de doctorat ès -science techniques. École polytechnique Fédérale de Lausanne EPEL, 252p.

Bossou Bertin, 2002. Analyse et esquisse cartographique de la contamination bactériologique de la nappe phréatique alimentant les puits traditionnels de la ville de Cotonou et sa banlieue. Mémoire de DESS/MEQUE, FAST, UAC, 82p+ annexes.

Boukari M., 1998. Fonctionnement du système aquifère exploité pour l'approvisionnement en eau de la ville de Cotonou sur le littoral béninois: impact du développement urbain sur la qualité des ressources. Thèse d'état es- sciences UCAD de Dakar et université National du Bénin, $277 p+$ annexes.

Chouti K. Waris, 2011. Étude de la pollution chimique d'une lagune, tropicale (eau, sédiments, poissons). Cas de la lagune de Porto-Novo (sud Bénin). Thèse de doctorat, spécialité chimie minérale, FAST, UAC

Chouti K. Waris, Mama Daouda, Alassane Abdoukarim, Changotade Odilon, Alapini François, Boukari Moussa, Aminou Taofic et Afouda Abel (2011). Caractérisation physico-chimique de la lagune de Porto-Novo (Sud Bénin) et mise en relief de la pollution par le mercure, le cuivre et le zinc. Journal of Applied Biosciences 43: 28822890.

Chouti K. Waris, Mama Daouda, Changotade Odilon, Alapini François, Boukari Moussa (2010). Étude des éléments traces métalliques contenus dans les sédiments de la lagune de Porto-Novo (Sud Bénin). Journal of Applied Biosciences P2186-2197.

Chouti K. Waris, Mama Daouda, Alapini François (2010). Étude des variations spatiotemporelles de la pollution des eaux de la lagune de Porto-Novo (Sud Bénin). Int. J.Biol. Chem. Sci. Volume 4 N4 P1017-1029.

Charle F., Bamory D. 1985. Expérimentation de solution en vue d'améliorer la qualité de l'eau à domicile en milieu rural, In Villand MC. Eau et santé. Abidjan INSP, SNES.

Dégbé Cyriaque, 2004. La qualité de l'eau de puits dans la commune d'Abomey - Calavi et les facteurs exogènes de sa pollution. Mémoire de fin de formation de DEA, Environnement et Santé Publique, FLASH, UAC, Bénin.

Empeureur- Bissonet P., Salzman V, Monjour L, 1992. Application d'un nouveau matériel de transport et de stockage pour l'amélioration de la qualité de l'eau de boisson en milieu rural africain. Bulletin de Société et de pathologie Exotique, $n^{\circ} 85$, P390-394.

Evens Emmanuel 2004. Évaluation des risques sanitaires et éco-toxicologiques liés aux effluents hospitaliers. Thèse de doctorat, INSA de Lyon, France.

El Haissoufi, S. Berrada, M. Merzouki, M. Aabouch, L. Bennani, M. Benlemlih, M. Idir, A. Zanibou, Y. Bennis, A. El Ouali Lalami, 2011. Pollution des eaux de puits de certains quartiers de la ville de FES, Maroc, Rev. Microbiol. Ind.San et Environn. Vol 5, N01, p : 37-68.

Fatombi K Jacques, Josse G. Roger, Mama Daouda, Aminou Taofic(2009). Étude de l'activité floculante de la caséine acide extraite de la crème de cocos nucifera dans la clarification des eaux de surface. Revue des sciences de l'eau. Volume 22, numéro 1, p 93-101.

Gomez Coami Ansèque ,2009. Étude de la qualité des eaux de consommation et état de santé des populations en milieu ITCHA-IFE dans le département des Collines au Bénin. Thèse de doctorat, Université d'Abomey-Calavi, FLASH, Géographie et Gestion de l'Environnement.

Hounsinou, 2012. Pollution chimique et bactérienne des eaux de pluie, des eaux de surface et des eaux souterraines dans la commune d'Abomey-Calavi (sud Bénin): Transfert de polluants entre l'air, le sol et l'eau.DEA en 
chimie minérale /FAST/Université d'AbomeyCalavi.

Louah M. (1995) : Écologie des culicidé (diptera) et état du paludisme dans la péninsule de Tanger. Thèse de doctorat, Université d'Abdelma ES SAADI, faculté des sciences Tétouan.

Maliki R. (1993). Étude hydrogéologique du littoral béninois dans la région de Cotonou (Afrique de l'Ouest). Thèse de doctorat de 3 ème cycle. UCAD/Dakar/ Sénégal. 162 p+annexes.

Mama Daouda, 2010. Méthodologie et résultats du diagnostic de l'eutrophisation du lac Nokoué (Bénin). Thèse de doctorat, spécialité sciences appliquées, Université de Limoge, France.

Mama Daouda, Matchi Bernard, Aina Martin, Issa Maman-Sanni, Moudachirou Mansourou et Matejka Guy (2010). Impact d'une décharge des déchets solides ménagers sur la ressource en eau: étude de cas. Bulletin d'Information de la SOACHIM ; 07 ; 1-14.

Mama Daouda, Aina Martin, Alassane Abdoukarim, Boukari Ousmane Touré, Chouti Waris, Deluchat Véronique, Bowen James, Afouda Abel et Baudu Michel (2011). Caractérisation physico-chimique et évaluation du risque d'eutrophisation du lac Nokoué (Bénin). Int. J.Biol. Chem. Sci. Volume 5 N5 P 2076-2093.

MAMA Daouda, AINA Martin, YAO Benjamin, Deluchat Véronique, Boukari Moussa, Guedegbe Bonaventure et Baudu Michel (2011). Effet de la mobilité du soufre et ses dérivés sur la qualité des eaux dans un contexte de dépôt mal contrôlé : étude de cas. Int. J.Biol. Chem. Sci. Volume $5 \mathrm{~N}^{\circ} 1 \mathrm{P}$ 80-93.

Rodier J., (1984). L'analyse de l'eau. (Livre) Dunod, Paris. 